\title{
Learning and knowledge trajectories in congregations
}

\author{
Elisabeth Tveito Johnsen / Geir Afdal
}

\begin{abstract}
Überblick
"Verlaufskurven des Lernens und Wissens in Gemeinden«: Dieses Forschungsprojekt begleitete eine umfassende Initiative zur religiösen Bildung der Kirche von Norwegen. Es zielte einerseits darauf, anspruchsvolle pädagogische Theorien wie die soziokulturelle Entwicklungspsychologie (Lew Vygotskij) oder die Akteur-Netzwerk-Theorie (Bruno Latour) in die religionspädagogische Forschung zu integrieren. Andererseits wurden faktische Lernprozesse in Taufunterricht, Kirchenvorstand, Konfi-Teams oder Gottesdienstplanung eingehend untersucht. Die außertheologische Rezeption von >LETRA< scheint erfolgreicher zu sein als seine innerkirchliche Wirkung.
\end{abstract}

\section{More Luther than Vygotskij}

Learning trajectories in congregations (LETRA) is a research project (2010-2014) on how learning and knowledge construction takes place in congregations. One key characteristic of LETRA is its combination of empirical and theoretical interests. LETRA analyzes learning and knowledge processes in congregations with a wide range of learning theories and practice theories. It contains empirical research on activities often associated with learning, such as religious education for children, confirmands and youth, but it also explores professional learning and knowledge of deacons and pastors.

A major reform of the Christian Education program in Church of Norway (CoN) is an important backdrop of LETRA. The reform, initiated by the church, but launched in 2003 by the Norwegian Parliament, aimed explicitly to educate all baptized children and youth between 0-18 in Christian faith. Politicians and the church argued that the non-confessional religious education in school made the reform necessary. The state, is was argued, had to provide the church, as well as religious- and life stance organizations, a possibility to transmit faith to their members. The first ten years, congregations could apply for funding for new and innovative Christian education projects. Some of these new ideas involved climbing walls, canoeing, baking and concerts, which sparked a discussion about learning. Theologians, and some sociologists, voiced worries about the theological content and argued for more learning and less entertainment. However, the discourse did not relate to theoretically grounded concepts of learning or more advanced pedagogical theories. In short, it was »a lot of Luther, but no Vygotskij «. LETRA has contributed to making research in congregations more developed on the pedagogical side.

\section{A pool of practice theories}

The LETRA project lasted for four years and was led by Professor Geir Afdal. The core group of LETRA consisted of scholars from MF School of theology, religion and society, four phd-students, Morten Holmqvist, Ingrid Reite Christensen, Marianne Rodiguez Ny-

${ }^{1}$ Geir Afdal: Menigheten som lærende fellesskap? Sosiokulturell læringsteoris muligheter og begrensninger som perspektiv på kirkelig læring, in: Prismet 59 (2008,4), 227-245. 
gaard and Fredrik Saxegaard, and two senior scholars, Heid Leganger-Krogstad and Sverre Dag Mogstad. Two external phd-students, Øyvind Holtedahl (VID Specialized University) and Elisabeth Tveito Johnsen (University of Oslo) were included during the period. Tone Stangeland Kaufman and Astrid Sandsmark from MF contributed as well during the project period. During the first year of LETRA the main activity was to educate ourselves in a pool of practice and learning theories. Fieldwork, primarily in three congregations, was conducted in year two, and analysis was the main activity in the two last years.

The theories in LETRA can be grouped in three: 1. socio-cultural learning theories, 2. activity theory and 3. socio-material theories. Common to all of them is a basic understanding that learning is a social practice. ${ }^{2}$ We will give brief examples of how researchers in LETRA have utilized the three different strands of theory. The examples focus on the PhD-thesis coming out of LETRA, and are only small snapshots from these extensive research projects.

\section{Socio-cultural learning}

Every socio-cultural learning theory claims that what people learn is dependent on how they learn. Learning is not something that comes afterwards as a result, but is in itself part of the activity. The basic claim of Lev Vygotskij, the founding father of this theoretical tradition, is that our experience of reality is always indirect, mediated by culturally and socially developed tools and signs. ${ }^{3}$ Etienne Wenger and Jean Lave have developed this insight further in their concepts of

Renegotiating the practice of worship legitimate peripheral participation and community of practice. ${ }^{4}$

Elisabeth Tveito Johnsen has used Lave and Wenger in her analysis of Sunday worship services being part of »Baptism clubs« in two congregations. She identifies that the children were involved in two kinds of tasks in Sunday services: performance tasks and liturgical tasks. The performance tasks; singing songs and acting based on a biblical text, followed by bowing and calls for acclamation, are common in worship services where children and their families are particularly invited. However, the questions raised by Lave and Wenger are how newcomers become participants in a practice as it usually is. Thus, to perform a play and to sing songs not part of regular Sunday services is to position children in an outbound learning trajectory. Performance skills are valuable in many practices, but not particularly helpful in order to guide children into the expected norms regulating Sunday services. However, the liturgical tasks the children took part in, such as walking into the sanctuary in procession, lighten candles during prayer, and to prepare the Eucharist together with the pastor, are legitimate tasks in a Sunday service, and the tasks, communal character takes care of the safety aspect of legitimate peripheral participation. Johnsen argues that liturgical tasks are necessary to learn the Sunday service practice. However, practices are not fixed. Performance tasks renegotiate Sunday services closer to other communities of practice, such as school and leisure practices. ${ }^{5}$

${ }^{2}$ Vgl. ders.: Researching Religious Education as Social Practice (Religious Diversity and Education in Europe 20), Münster/New York/München/Berlin 2010.

${ }^{3}$ Vgl. Lev Semenovič Vygotskij/Michael Cole/Vera John-Steiner/Sylvia Scribner/Ellen Souberman: Mind in society. The development of higher psychological processes, Cambridge 1978.

${ }^{4} \mathrm{Vgl}$. Jean Lave/Etienne Wenger: Situated learning. Legitimate peripheral participation. Learning in doing, Cambridge 1991; Etienne Wenger: Communities of Practice. Learning, Meaning, and Identity. Learning in doing: social, cognitive, and computational perspectives, Cambridge 1998.

${ }^{5}$ Vgl. Elisabeth Tveito Johnsen: Religiøs læring i sosiale praksiser. En etnografisk studie av mediering, identifisering og forhandlingsprosesser i Den norske kirkes trosopplæring, 0slo 2014; dies.: Gudstjenestelæring gjennom deltagelse, in: Geir Hellemo (Hg.): In Gudstjeneste på ny, 0slo 2014, 151-177. 
Morten Holmqvist utilizes both social cultural theories and socio-material theories in his research on confirmation in congregations. ${ }^{6}$ In an article discussing two episodes of prayer at confirmation camps, ${ }^{7}$ James Wertsch's concept of affordances and constrains of cultural tools plays a pivotal analytical role, ${ }^{8}$ combined with Schatzki's concept of timespace trajectories. ${ }^{9}$ One of the situations discussed by Holmqvist is an outing into the forest in the evening. It is dark and the confirmands are supposed to walk silently in groups through a candle path, with small posters with verses from the Bible, ending down by the sea with a huge bonfire. The youth leaders really looked forward to see the confirmands touched by the experience, but it did not turn out the way they expected. The confirmands were not silent. They did not understand what to do with the posters, and showed no feelings of being touched when they arrived at the bonfire. Holmqvist analyses the discrepancy between the youth leaders and the confirmands as a result of

Candle path as quiz or prayer their different experience with the employed cultural tools and that they live in different time-space trajectories. The path and the posters were new to the confirmands, and they were unable to break the cultural code inherited in the material objects. They did not recognize it as an invitation to meditative prayer, and thought it was some kind of quiz. The leaders had been part of the path many times, and felt deeply emotional about it, several cried when they walked the path alone after the confirmands were in bed. The confirmands, however, were not on this path, or trajectory. The tools did not mediate reality to the confirmands as they did to the youth leaders. Lack of information and previous experience constrained their interaction with the tools. ${ }^{10}$

\section{Activity theory}

This second theoretical tradition in LETRA is concerned about how organizations learn, and not how newcomers become part of communities. Fredrik Saxegaard employs Yrjö Engeström ${ }^{11}$ in his analysis of congregations that are in processes of change, and particularly how pastors negotiate their role as leaders within these processes. ${ }^{12}$ One of the congregations studied by Saxegaard was tormented with conflicts and the need for change was urgent, but it was difficult for the people involved to identify how and to what. The turning point for the local pastor came one Sunday morning before the worship service. One of the ushers came running in to his office telling him that »someone has put a baby on the floor in front of the altar « ${ }^{13}$. The pastor came into the sanctuary, saw the baby on

${ }^{6}$ Vgl. Morten Holmqvist: The Material Logics of Confirmation, in: International Journal of Actor-Network Theory and Technological Innovation 6 (2014,4), 26-37; ders./Geir Afdal: Modes Of Learning And The Making Of Religion. The Norwegian And Finnish Curricula For Confirmation, in: Nordic Journal of Religion and Society 28 (2015,1), 1-20.

${ }^{7}$ Vgl. Morten Holmqvist: Learning Religion. Exploring Young People's Participation Through Timespace and Mediation at Confirmation Camp, in: Mind, Culture, and Activity 22 (2015,3), 201-216.

${ }^{8}$ Vgl. James Wertsch: Mind as action, New York 1998.

${ }^{9}$ Vgl. Theodore R. Schatzki: The timespace of human activity. On performance, society, and history as indeterminate teleological events, Toposophia/Lanham 2010.

${ }^{10} \mathrm{Vgl}$. Holmqvist 2015.

${ }^{11}$ Vgl. Yriö Engeström: From Teams to Knots. Activity-Theoretical Studies of Collaboartion and Learning at Work (Learning in Doing: Social, Cognitive \& Computational Perspectives), Cambridge 2008; ders.: Learning by expanding. An activity-theoretical approach to developmental research, New York ${ }^{2} 2015$.

${ }^{12}$ Vgl. Fredrik Saxegaard: Realizing church. Parish pastors as contributors to leadership in congregations (Nordic Studies in Theology/Nordische Studien zur Theologie 6), Münster 2020 (erscheint in Kürze).

${ }^{13}$ A.a.0., 233. 
the floor, and the mother, with an Asian look, sitting close by. The mother was not able to speak Norwegian very well, but the pastor understood that she wanted him to bless her child. He lifted the baby and pronounced a blessing, before he gave the child back to the mother. ${ }^{14}$

This became a decisive moment for the pastor. It made him realize that the congregation had to open up for the immigrant population living in their parish. The pastor proposed several initiatives to invite immigrant groups into the church, both Christian and Muslim groups, like offering free rent to the church building. The parish board members were not necessarily negative to these new ideas, but few of them articulated explicit support. Saxegaard shows that one of the things that made this demanding process possible was a language tool. The changes were presented as a project, and not as something permanent. This made it easier to get support both internally, and externally, for instance for funding. Eventually, the object, what they as congregation communally aimed at, became transformed. Saxegaard shows how a contradictive process of negotiating tools, rules and division of labor enabled the congregation to expand their object from being congregation for the Norwegian middle class population to become a place beyond religious divides. ${ }^{15}$ As Saxegaard points out, pastors also apply theological tools to lead congregations. Hence, Marianne Rodriguez Nygaard shows how theological language tools effectively undermine deacons' effort to make things happen in congregations. Nygaard utilizes Paavola and Hakkarainen's concept of knowledge creation to analyze how deacons understand themselves and their work. ${ }^{16}$ Nygaard describes how deacons' initiatives, such as »open church«, are turned down or not given proper attention. The staff are mostly concerned about their own tasks and do not have the capacity to engage in collaborative work. The deacons report that it is hard for them to make

Deacons crossing boundaries themselves heard as profession among the other church professions. ${ }^{17}$ However, Nygaard also shows that deacons are creative in their work. One of the stories is about a deacon inviting a Romanian woman, »Elana«, for coffee in her office, and later to a whole range of church activities, such as seminars in and beyond the congregation. Nygaard claims that deacons engage in knowledge creation by trespassing constraints set by the formal organization and work culture within congregations. Thus, the study provide examples of how deacons' make congregations expand their practices by boundary crossing activities. ${ }^{18}$

\section{Socio-material theories}

The third theoretical tradition that LETRA that employs is socio-material theories, particularly as it is it developed within actor-network theory (ANT) by Bruno Latour. ${ }^{19}$ Ingrid Reite

\footnotetext{
14 Vgl. ebd.

${ }^{15}$ Vgl. ebd.

${ }^{16}$ Vgl. Sami Paavola/Kai Hakkarainen: The Knowledge Creation Metaphor - An Emergent Epistemological Approach to Learning, in: Science \& Education. Contributions from History, Philosophy and Sociology of Science and Mathematics 14 (2005,6), 535-557.

${ }^{17}$ Vgl. Marianna Ridriguez Nygaard: Caring to know or knowing to care? Knowledge Creation and Care in Deacons' Professional Practice in the Church of Norway, Phd thesis/Det teologiske menighetsfakultet 2015.

${ }^{18} \mathrm{Vgl}$. ebd.

${ }^{19}$ Vgl. Bruno Latour: Science in action. How to follow scientists and engineers through society, Milton Keynes 1987; ders.: Reassembling the social. An introduction to actor-network-theory, 0xford 2005.
} 
Christensen has conducted research on how pastors do their work within congregations. ${ }^{20}$ Reite has studied how the liturgical Sunday service reform, launched at the same time as the Christian education reform, affects the everyday work of pastors. Reforms aim at making something better, but Reite shows that reform is a non-human actor that interacts with human and nonhuman actors already present in the life of congregations. One of the situations she dwells into takes place before Christmas, only a week or two after every congregation where obliged to apply new liturgies and new liturgical music. ${ }^{21}$ Two pastors and a cantor gather to plan the upcoming Sunday service. They have the liturgy binder containing the new liturgies at the table in front of them. The meeting starts and one of the pastors begins to browse the binder, he puts it away, and the cantor starts doing the same suggesting if they can take it chronologically form the top, and proceed through the service. The pastor takes over and browses the binder again, being in a state of indecisiveness, the other takes over and suggest that they use the liturgy from last year, and mix in some of the new elements. They continue to browse the binder, and end up deciding to skip the reform and do as they did last year. ${ }^{22}$ Reite holds that reforms

Reform as a bring different dynamics into action, and high-powered learning dynamics non-human actor are just one out of several possible outcomes. It depends on the various dynamics the reforms interacts with local work environments. Her analysis also shows that reforms are not implemented, as argued by the strategical top-level of an organization, such as the Church council in Church of Norway. Rather, reforms are enacted into being by those who receive it. Pastors in congregations are not just adjusting to the liturgy reform, and every other reform, they recreate it, ignore it and replace it.

One scholar who has contributed substantially to ANT is John Law. ${ }^{23}$ The particularity of Law's ANT approach is that he foregrounds issues of power. This interest in how power is embedded in materiality is a key concern in Øyvind Holtedahl's research. Youth ministry is, as different from most Christian education in Church of Norway, regular, frequent gatherings for committed young people aged 15-18. Holtedahl finds that enactments of community is a central mode within the youth ministries. His analysis demonstrates that this mode features »closeness, intimacy, and fellowship, with similarities to family life and the youths' private lives at home $\aleph^{24}$. One of the key actors that makes this mode possible, largely unnoticed by the youth themselves, are some sofas. Holtedahl describes that the sofas gradually caught his attention, partly because the youth asked him for help to carry them several times. The sofas were in the café area in the beginning of the evening, and moved into the sanctuary before the worship service began. It did not happen once; they

\footnotetext{
${ }^{20} \mathrm{Vgl}$. Ingrid Reite: Between settling and unsettling in a changing knowledge society: The professional learning trajectories of pastors, PhD- thesis/Det teologiske menighetsfakultet 2014; Ingrid Reite Christensen: How to educate professionals for learning new knowledge? A comparison of learning approaches in Dutch and Norwegian pastor education, in: Prismet 67 (2016,2) 93-106.

${ }^{21} \mathrm{Vgl}$. Ingrid Reite: Pastors and the perpetuum mobile. The dynamics of professional learning in times of reform, in: Pedagogy, Culture \& Society 53 (2015), 389-409.

${ }^{22}$ Vgl. a.a.0. 402.

${ }^{23}$ Vgl. John Law: Organizing modernity, 0xford 1994; ders.: Ordering and Obduracy, Centre for Science Studies/ Lancaster University 2001/2003: https://www.lancaster.ac.uk/fass/resources/sociology-online-papers/papers/ law-ordering-and-obduracy.pdf (14.02.20); ders./John Hassard: Actor network theory and after (The Sociological review monographs), 0xford 1999.

${ }^{24}$ Øivind Knobloch Holtedahl: »Community«, »God from above« and »God from below«. An ethnographic study of religious knowledge practices in two youth ministries in the Church of Norway (no. 5), VID Specialized University, Stavanger 2017, 9.
} 
reorganized the room every time they gathered. Chairs out and sofas in. Asked about the sofas, the youth replied that they would have been much more stilted and formal if everyone sat on their own chairs. The sofas made them relax, they made it cozy and they felt at home. ${ }^{25}$ Hence, Holtedahl shows that the sofas are an actor in a network established within the youth ministry. To remove the sofas would make them sit on chairs, something that they associate with the adult Sunday service. The sofa empowers the youth to enact another kind of religious community than they find among adults. Not to reorganize the room would bring them into the dominating adult mode of worship services. The chairs materiality would simply put them into a stiff and boring mode of practicing faith. Sofas on the other hand opened a space for a cozy mode of religious practice. ${ }^{26}$

\section{Impact and domestication of LETRA}

LETRA has not followed a traditional practical theological research trajectory. The project has fostered more respect and interest in what kind of insights pedagogical tools can offer. The research strategy has been to explore the field analytically, but not to offer solutions to what congregations can to do improve their practice. Most of the articles are in journals not associated with theology at all. Thus, the most visible impact of LETRA has been to bring congregational practices into scholarly discussions outside theological frameworks. To publish in journals known for their advanced theoretical level has been encouraged and part of the scholarly fields aim for some LETRA scholars. Others in LETRA have sent their articles to practical theological journals. The responses have been more negative, often demanding major revisions or rejection. Specialized theoretical journals have approved the very same articles with minor changes.

Another area of impact has been in curricula and research projects at different levels in theology, religious education and diaconia at the major theological institutions in Norway, and in other Nordic countries. References to Vygotskij are not as absent as they were in 2008. However, the impact has almost domesticated some of the theoretical perspectives employed and developed by LETRA. Continually to look for analytical tools that are able to say something new and unexpected about learning in congregations are important. Our knowledge about reality will always be indirect and mediated. To turn Vygotskij, Wenger, Engeström and Latour into a normative trajectory will be against the fundamental insights they have learned us about research and congregations.

Dr. Elisabeth Tveito Johnsen ist Associate professor für Religionspädagogik an der Universität Oslo; sie hat ihre Promotion im Rahmen des LETRA-Projekts geschrieben.

E-Mail: e.t.johnsen@teologi.uio.no

Prof. Dr. Teol Geir Afdal ist Erziehungswissenschaftler an der Kirchlichen Fachhochschule (Teologiske Menighetsfakultet) für Theologie, Religion und Gesellschaft in Oslo und Direktor der interuniversitären Graduiertenschule »Research School Religion-Values-Society«, an der das hier vorgestellte Projekt angesiedelt war. E-Mail: Geir.Afdal@mf.no

${ }^{25} \mathrm{Vgl}$ a.a.0., 125.

${ }^{26} \mathrm{Vgl}$. ebd. 